\title{
KERJA SAMA ANTARA GURU DENGAN SISWA SELAMA PEMBELAJARAN DARING DI MASA PANDEMI COVID-19
}

\author{
Maulina Hendrik, Diana Pramesti \\ Pendidikan Guru Sekolah Dasar, Universitas Muhammadiyah Bangka Belitung \\ Correspondence Email: maulina.hendrik@stkipmbb.ac.id
}

\begin{abstract}
This research aimed to describe: 1) the implementation of learning while learning from home during the Covid-19 epidemic; 2) a form of cooperation between students and teachers during online learning during the Covid-19 pandemic at SD STKIP Muhammadiyah Bangka Belitung; and 3) factors that hinder the establishment of cooperation between teachers and students during online learning. This research is qualitative research using a qualitative exploratory research design. The primary data sources of this study were teachers of class IVA and IVB, parents of students, and students of SD STKIP Muhammadiyah Bangka Belitung and the secondary data sources of this study were articles of relevant research results and other related references. This research data collection using in-depth interview techniques, questionnaires, direct observation, documentation, and archival records. The data analysis of this study used the Miles and Huberman analysis technique in 3 stages, namely data reduction, data presentation, and drawing conclusions. The results of data analysis show: 1) The pattern of learning implementation at SD STKIP Muhammadiyah Bangka Belitung during learning from home during the Covid-19 period was virtual and door to door face-to-face. 2) Cooperation between teachers and students is quite good during online learning based on 3 indicators: attendance on time, respect for teacher and peer opinions, and completing assignments on time. $55 \%$ of students who attend on time during online learning. Students who value / listen to their friends' opinions when learning use zoom as much as 79\%, and students who always submit assignments to the teacher on time as much as 48\%.3) factors that hinder the establishment of cooperation between teachers and students during online learning, namely: student enthusiasm, learning facilities and infrastructure, the role and competence of parents, and practicum-based subjects.
\end{abstract}

Keywords:

form of cooperation, online learning

\begin{abstract}
Abstrak
Penelitian ini bertujuan untuk mendeskripsikan: 1) pelaksanaan pembelajaran selama belajar dari rumah di masa pendemi Covid-19; 2) wujud kerja sama antara siswa dengan guru selama pembelajaran daring pada masa pandemi Covid-19 di SD STKIP Muhammadiyah Bangka Belitung; dan 3) faktor-faktor yang menghambat terjalinnya kerja sama antara guru dengan siswa selama pembelajaran daring. Penelitian ini merupakan penelitian kualitatif dengan menggunakan desain penelitian kualitatif eksploratif. Sumber data primer penelitian ini guru kelas IVA dan IVB, orangtua siswa, dan siswa SD STKIP Muhammadiyah Bangka Belitung dan sumber data sekunder penelitian ini artikel hasil penelitian yang relevan dan referensi lainnya yang terkait. Pengumpulan data penelitian ini menggunakan teknik wawancara mendalam, angket, observasi langsung, dokumentasi, dan rekam arsip. Analisis data penelitian ini menggunakan teknik analisis Miles dan Huberman dalam 3 tahapan, yaitu reduksi data, penyajian data, dan penarikan simpulan. Hasil analisis data menunjukkan: 1) Pola pelaksanaan pembelajaran di SD STKIP Muhammadiyah Bangka Belitung selama belajar dari rumah di masa Covid-19 adalah secara virtual dan tatap muka door to door. 2) Kerja sama antara guru dan siswa cukup baik selama pembelajaran daring berdasarkan 3 indikator: hadir tepat waktu, menghargai pendapat guru dan teman sebaya, dan menyelesaikan tugas tepat waktu. Siswa yang hadir tepat waktu selama pembelajaran daring sebanyak $55 \%$. Siswa yang menghargai/menyimak pendapat temannya saat belajar menggunakan zoom sebanyak $79 \%$, dan siswa yang selalu menyerahkan tugas kepada guru tepat waktu sebanyak 48\%. 3) faktor-faktor
\end{abstract}


yang menghambat terjalinnya kerja sama antara guru dengan siswa selama pembelajaran daring yaitu: antusias siswa, sarana dan prasarana pembelajaran, peranan dan kompetensi orang tua, serta mata pelajaran berbasis praktikum.

Kata kunci:

wujud kerja sama, pembelajaran daring

\section{A. PENDAHULUAN}

Pandemi Covid-19 merupakan musibah yang mengakibatkan dunia mengalami krisis kesehatan. Seluruh segmen kehidupan di muka bumi ini yang sedang menjalankan perubahan dunia 4.o menjadi terganggu termasuk dunia pendidikan. Grafik kasus positif Covid-19 setiap harinya terus meningkat. Hingga 28 April 2020, kasus positif Covid-19 di Indonesia sebanyak 9.511 kasus. Pada akhirnya, beberapa provinsi menerapkan Pembatasan Sosial Berskala Besar (PSBB) dalam rangka percepatan penanganan Covid-19. Semua aktivitas dihentikan dengan adanya peraturan tersebut termasuk kegiatan pembelajaran dari PAUD hingga pendidikan tinggi dilakukan dari rumah atau disebut dengan study from home (SFH).

Dampak bagi keberlangsungan pendidikan tersebut mengejutkan bagi seluruh pelaku pendidikan. Banyak keluarga yang kurang familiar melakukan sekolah dari rumah. Bagi orang tua yang sibuk dengan aktivitas di luar rumah, ini sangat mengejutkan. Secara psikologis siswa belum terbiasa belajar jarak jauh bersama gurunya, fasilitas di rumah tidak seperti fasilitas

${ }^{1}$ Rizqon H Syah, "Dampak Covid-19 Pada Pendidikan Di Indonesia: Sekolah, Keterampilan, Dan Proses Pembelajaran," SALAM: Jurnal Sosial Dan Budaya Syar-I, 2020, https://doi.org/10.15408/sjsbs.v7i5.15314.

${ }^{2}$ Agus Purwanto et al., "Studi Eksploratif Dampak Pandemi COVID-19 Terhadap di sekolah ${ }^{1}$. Selain itu, hasil penelitian ${ }^{2}$ menyatakan para orang tua harus menyediakan biaya pembelian kuota internet karena pembelajaran daring yang memanfaatkan teknologi harus menggunakan data internet.

Lebih lanjut ${ }^{3}$ juga menyatakan dampak lainnya yang disebabkan hadirnya pandemi ini adalah kelemahan guru yang kurang mahir mengaplikasikan teknologi online atau media sosial sebagai sarana pembelajaran seperti whatsapp group, zoom meeting, google classroom. Banyak guru senior di Sekolah Dasar yang berusia di atas 50 tahun sulit berinteraksi dengan siswa melalui pembelajaran daring sehingga harus beradaptasi terlebih dahulu. Selain itu, bagi para guru khususnya guru SD belum ada budaya belajar jarak jauh karena selama ini guru SD lebih banyak mengasuh anak didik agar tertanam karakter yang positif.

Meskipun dunia sedang dilanda krisis kesehatan, pembentukan karakter dalam diri siswa tidak dapat dihentikan. Pendidikan karakter di jenjang tingkat Sekolah Dasar (SD) memiliki peranan yang sangat penting untuk diterapkan di sekolah. 4 Sebelum hadirnya pandemi

Proses Pembelajaran Online Di Sekolah Dasar," EduPsyCouns: Journal of Education, Psychology and Counseling, 2020.

${ }^{3}$ Purwanto et al.

4 Diana Pramesti and Adevia Indah Kusuma, "Implementasi Nilai Kewirausahaan Jenjang Sekolah Dasar 
Covid-19 pemerintah telah mendesain kurikulum pembelajaran berbasis pendidikan karakter yang saat ini disebut dengan kurikulum Abad 21. Ciriciri pembelajaran Abad 21 adalah peserta didik memiliki 4 kompetensi $\left({ }_{4} \mathrm{C}\right)$, yaitu critical thinking, communication, collaboration, and creativity. Konsep pendidikan yang dibangun di era ini yaitu digitalisasi dan komputerisasi. Peserta didik dan pendidik yang hidup di Abad 21 harus mampu menyesuaikan perkembangan zaman. Sejalan dengan hal tersebut ${ }^{5}$ juga menyebutkan siswa yang hidup di zaman tersebut harus menguasai keilmuan, berketerampilan metakognitif, mampu berpikir kritis dan kreatif, serta bisa berkomunikasi atau berkolaborasi efektif.

Menjawab tantangan perubahan zaman tersebut, Kementerian Pendidikan dan Kebudayaan telah merancang pembelajaran Abad 21 di dalam Kurikulum 2013 yang berpusat pada peserta didik yaitu berpikir kritis, mampu berkomunikasi, mampu berkolaborasi dengan cara berdiskusi/ bekerja sama, dan kreatif. Untuk menunjang pembelajaran Kurikulum 2013 Abad ke-21, Kementerian Pendidikan dan Kebudayaan meluncurkan program unggulan Gerakan Literasi Sekolah (GLS). GLS merupakan suatu usaha atau kegiatan yang bersifat partisipatif dengan melibatkan warga sekolah, akademisi,

Pada Sekolah Mitra Stkip Muhammadiyah Bangka Belitung Di Kecamatan Gabek Kota Pangkalpinang," Jurnal Ekonomi Dan Pendidikan 17, no. 1 (2020): 1-6, https://doi.org/10.21831/jep.v17i1.29256.

5 Laura Greenstein, "Assessing 21st Century Skills: A Guide to Evaluating Mastery and Authentic Learning," Assessing 21st Century Skills: A Guide to praktisi, masyarakat, maupun dunia usaha ${ }^{6}$. GLS sangat penting untuk mengembangkan kemampuan peserta didik misalnya meningkatkan minat membaca dengan menerapkan kebiasaan membaca 15 menit sebelum/ sesudah pembelajaran. Program GLS yang didesain diharapkan mampu mengembangkan karakter atau pekerti peserta didik.

Berdasarkan hasil wawancara terhadap Kepala Sekolah SD STKIP Muhammadiyah Bangka Belitung, sejak adanya edaran pembelajaran dari rumah oleh Pemerintah Kabupaten Bangka Tengah, semua aktivitas di sekolah dilakukan dari rumah. Peserta didik belajar dari rumah sedangkan guru tetap berada di sekolah untuk menyiapkan perangkat pembelajaran daring hingga mengimplementasikannya. Meskipun pada akhirnya guru juga dirumahkan atau beraktivitas dari rumah karena kasus positif Covid-19 yang terus meningkat di Provinsi Kepulauan Bangka Belitung.

Tantangan yang dihadapi guru SD STKIP Muhammadiyah Bangka Belitung salah satunya adalah pembiasaan kegiatan di luar jam pelajaran yang selama ini dilakukan bersama di sekolah beralih pembiasaan dari rumah masingmasing. Contohnya: setiap hari sebelum pembelajaran dimulai, biasanya siswa bersama guru melaksanakan shalat

Evaluating Mastery and Authentic Learning, 2012.

${ }^{6}$ Pangesti Wiedarti and Kisyani Laksono, Panduan Gerakan Literasi Sekolah Di Sekolah Dasar, Direktorat Pembinaan Sekolah Dasar Direktorat Jenderal Pendidikan Dasar Dan Menengah Kementerian Pendidikan Dan Kebudayaan, 2016, https://doi.org/10.1007/s10029-0171595-x. 
dhuha berjamaah, pembiasaan membaca 15 menit sebelum pembelajaran dimulai. Dikarenakan adanya kebijakan belajar dari rumah, maka pembiasaan shalat dhuha dan kegiatan membaca harus dilaksanakan di rumah masing-masing. Menurut laporan guru SD STKIP Muhammadiyah Bangka Belitung, setiap guru kelas menunggu laporan dari para orang tua setiap pagi hari.

Selain itu, kegiatan yang biasa dilakukan bersama-sama adalah berdiskusi. Berdiskusi merupakan salah satu metode pembelajaran yang sangat efektif untuk meningkatkan kemampuan berkomunikasi seperti yang diharapkan pembelajaran Abad 21. Di dalam kegiatan berdiskusi, siswa diajak untuk dapat bekerja sama dengan timnya dan dituntut untuk dapat bercerita atau menjelaskan kembali kepada teman-teman yang lainnya.

$$
\text { Kerja sama merupakan }
$$
kompetensi yang diharapkan dalam pembelajaran Abad 21. Pembelajaran Abad 21 di era tatanan baru (new normal) yang saat ini dialami oleh seluruh pelaku pendidikan di Indonesia menuntut kerja sama yang baik agar aktivitas tetap berjalan maksimal. Guru dan siswa dituntut mampu bekerja sama dengan baik melalui pembelajaran daring (PJJ).

Hasil penelitian ${ }^{7}$ tentang Pendidikan Karakter Kerja Sama dalam Pembelajaran Siswa Sekolah Dasar pada

${ }^{7}$ Silvi Dwi Yulianti, Eri Tri Djatmika, and Anang Susanto, "Pendidikan Karakter Kerja Sama Dalam Pembelajaran Siswa Sekolah Dasar Pada Kurikulum 2013," Jurnal Teori Dan Praksis Pembelajaran IPS, 2016 , https://doi.org/10.17977/um022v1i12016p 033.
Kurikulum 2013 menyebutkan karakter kerja sama mampu meningkatkan kemampuan berinteraksi dan percaya diri siswa. Namun, dalam pelaksanaannya ditemukan adanya kendala dari luar dan dalam lingkungan pendidikan yaitu perubahan tata nilai, norma, budaya bangsa yang bebas. Sedangkan kendala internal meliputi mindset, kebijakan pendidikan, dan kurikulum.

Manusia merupakan makhluk sosial yang secara naluriah akan senantiasa bekerja sama dengan manusia lainnya. Kerja sama merupakan salah satu karakter manusia. Departemen Health and Human Services Amerika Serikat menyatakan "Pentingnya kemampuan psikososial, khususnya emosi dan sosial, yang meliputi: percaya diri, kemampuan kontrol diri, kemampuan bekerja sama, kemudahan bergaul, kemampuan berkonsentrasi, rasa empati, dan kemampuan berkomunikasi ${ }^{8}$. Setiap manusia memiliki karakter kerja sama yang berbeda-beda sehingga terkadang terjadi kesalahpahaman dalam melakukan sesuatu secara bersama.

Berdasarkan permasalahan tersebut, secara umum penelitian ini bertujuan untuk mengeksplorasi pelaksanaan pembelajaran dari rumah (study from home) yang berlangsung di masa pandemi Covid-19 pada siswa Kelas IV SD STKIP Muhammadiyah Bangka Belitung. Secara khusus,

8 Noviana Dewi and Stefanus Khrismasagung Trikusumaadi, "Bahaya Kecanduan Internet Dan Kecemasan Komunikasi Terhadap Karakter Kerja Sama Pada Mahasiswa," Jurnal Psikologi, 2017, https://doi.org/10.22146/jpsi.16829. 
penelitian ini bertujuan untuk mengeksplorasi wujud kerja sama antara siswa dengan guru selama pembelajaran daring pada masa pandemi Covid-19 di SD STKIP Muhammadiyah Bangka Belitung; dan faktor-faktor yang menghambat terjalinnya kerja sama antara guru dengan siswa selama pembelajaran daring.

Penelitian ini menggunakan desain penelitian studi kasus eksploratif dengan pendekatan metode kualitatif. Desain penelitian studi kasus eksploratif adalah suatu desain penelitian yang mengidentifikasi kasus untuk suatu studi. Kasus tersebut terikat oleh waktu dan tempat, dan menggunakan berbagai sumber informasi dalam pengumpulan data untuk memberikan penguatan terhadap data yang dikumpulkan ${ }^{9}$.

Sumber data penelitian ini terbagi 2, yaitu informan dan informasi. Sumber informasi adalah orang yang menceritakan tentang keadaannya/ diri sendiri sedangkan sumber informan adalah orang yang memberikan informasi tentang sumber informasi. Oleh karena itu, sumber data penelitian ini kepala sekolah, guru kelas, orang tua siswa, dan siswa kelas IV. Sumber data penelitian sekunder penelitian ini adalah referensi yang relevan dengan penelitian ini.

Lokasi penelitian ini di SD STKIP Muhammadiyah Bangka Belitung beralamat di Jalan K.H. Ahmad Dahlan Desa Mangkol Kecamatan Pangkalan Baru, Kabupaten Bangka Tengah, Provinsi Kepulauan Bangka Belitung

${ }_{9}^{9}$ J.W. Creswell and J. David Creswell, Research and Design Qualitative, Quantitative and Mixed Methods Approaches, Thousand Oaks California, 2018. selama 5 bulan sejak AgustusDesember 2020.

Penelitian ini dilakukan dalam 3 tahapan, yaitu: tahap orientasi, tahap eksplorasi, dan tahap member chek ${ }^{10}$. Pertama, pada tahap orientasi peneliti sebagai instrumen utama mencari informasi seluas-luasnya dari hal-hal yang bersifat umum berkenaan dengan masalah penelitian. Pada tahap ini, peneliti menciptakan hubungan yang harmonis dengan responden penelitian. Tujuan dari tahapan ini yaitu untuk menemukan permasalahan, berdiskusi dengan pihak-pihak terkait, maupun melalui studi kepustakaan. Selanjutnya, peneliti menentukan subjek penelitian, menetapkan instrumen penelitian, dan metode analisis data. Kedua, pada tahap eksplorasi, peneliti mengumpulkan data sesuai dengan fokus penelitian. Informasi yang dikumpulkan tidak lagi bersifat umum tapi lebih mengarah kepada rumusan permasalahan. Pengumpulan data pada tahapan ini secara alami, memotret peristiwa yang terjadi tanpa adanya manipulasi karena penelitian studi kasus merupakan penelitian kualitatif. Kegiatan yang dilakukan dalam tahap ini yaitu melakukan wawancara dengan responden, mengobservasi langsung secara terarah. Instrumen yang digunakan dalam penelitian ini adalah pedoman wawancara mendalam (depth interview), lembar observasi, dan angket. Ketiga, tahap Member Chek. Tahap ini bertujuan untuk mengecek kebenaran data yang diberikan sehingga data yang diberikan dapat dipercaya

10 Mudjia Rahardjo, "STUDI KASUS DALAM PENELITIAN KUALITATIF: KONSEP DAN PROSEDURNYA," Repository UIN MALANG, 2017. 
kebenarannya. Pengecekan data dilakukan dengan cara: 1) mengonfirmasi kembali hasil atau data yang diperoleh kepada sumber data; 2) meminta hasil koreksi yang telah dicatat dari hasil observasi kepada sumber data; 3) melakukan triangulasi dengan pihakpihak yang relevan. Data yang telah terkumpul dianalisis menggunakan teknik analisis data kualitatif deskriptif dengan 3 tahapan, yaitu: data reduksi, penyajian data, dan verifikasi.

\section{B. HASIL DAN PEMBAHASAN}

Penelitian ini dilaksanakan selama 3 bulan sejak September-November 2020 secara tatap muka maupun virtual. Subjek penelitian ini adalah kepala sekolah, guru kelas I, III, dan V, dan siswa SD STKIP Muhammadiyah Bangka Belitung. Penelitian ini bertujuan untuk mendeskripsikan: 1) pelaksanaan pembelajaran selama belajar dari rumah (BdR) di masa pendemi Covid-19, 2) wujud kerja sama antara guru dengan siswa selama BdR, dan 3) faktor-faktor yang menghambat selama pembelajaran dari rumah. Pengumpulan data penelitian ini menggunakan teknik wawancara mendalam dan observasi pelaksanaan pembelajaran.

\section{Pelaksanaan pembelajaran SD} STKIP Muhammadiyah Bangka Belitung selama belajar dari rumah (BdR) di masa pandemi Covid-19

SD STKIP Muhammadiyah Bangka

Belitung menerapkan pembelajaran dari rumah sejak berlakunya kebijakan pemerintah pusat maupun pemerintah daerah tentang pelaksanaan pembelajaran masa darurat Covid-19.

11 Asmuni, "Problematika Pembelajaran Daring Di Masa Pandemi Covid-19 Dan
Menteri Pendidikan dan Kebudayaan mengeluarkan surat Edaran Nomor 4 Tahun 2020 tentang Pelaksanaan Kebijakan Pendidikan dalam Masa Darurat Penyebaran Covid-19 pada 24 Maret 2020. Seluruh pemerintah daerah menindaklanjuti edaran tersebut dengan mengeluarkan kebijakan yang disesuaikan dengan kondisi daerah masing-masing termasuk Kebijakan Kepala Dinas Pendidikan Kabupaten Bangka Tengah, Provinsi Kepulauan Bangka Belitung menerapkan sistem Belajar dari Rumah (BDR) dengan sistem Pembelajaran Jarak Jauh (PJJ).

Undang-undang No. 20 tahun 2003 pasal 1 ayat 15 menjelaskan PJJ adalah pendidikan yang peserta didiknya terpisah dari pendidik dan pembelajarannya menggunakan berbagai sumber belajar melalui teknologi komunikasi, informasi dan media lain. Pelaksanaannya, PJJ dibagi menjadi dua pendekatan, yaitu pembelajaran jarak jauh dalam jaringan (daring) dan pembelajaran jarak jauh luar jaringan (luring). Dalam pelaksanaan PJJ, satuan pendidikan dapat memilih pendekatan (daring atau luring atau kombinasi keduanya) sesuai dengan karakteristik dan ketersediaan, kesiapan sarana dan prasarana. ${ }^{1}$

Kepala SD STKIP Muhammadiyah Bangka Belitung saat diwawancarai pada 28 September 2020 mengatakan "Saat menerima informasi tersebut, Saya langsung berkoordinasi dengan yayasan untuk menanggapi surat dari Kepala Dinas Pendidikan Kabupaten Bangka Tengah. Sejujurnya, informasi ini membuat kami hingga jajaran guru shock, walaupun kami sudah mengetahui kondisi Covid-19 yang

Solusi Pemecahannya" 7, no. 4 (2020): 281-88. 
sangat luar biasa di pulau Jawa khususnya. Kami masih belum percaya musibah ini akan sampai di lingkungan kita sendiri."

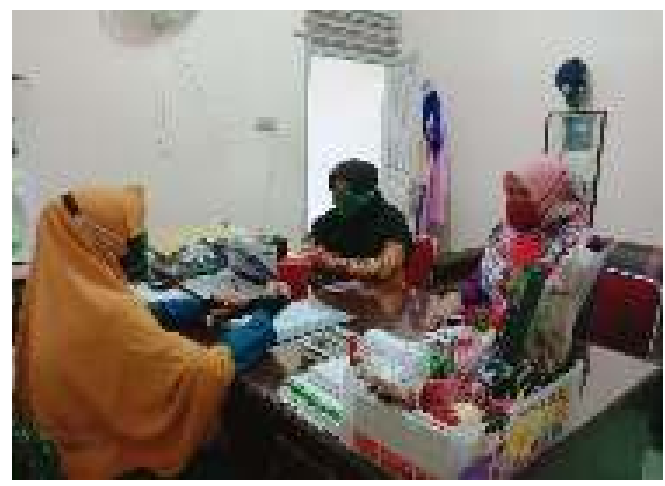

Gambar 1.

Wawancara Kepala SD STKIP Muhammadiyah Bangka Belitung

Setelah berkoordinasi dengan pihak yayasan pengelola yaitu Ketua dan wakil ketua STKIP Muhammadiyah Bangka Belitung, Kepala SD STKIP Muhammadiyah Bangka Belitung mengeluarkan surat pemberitahuan kepada para orang tua siswa kelas 1 hingga kelas 5 bahwa pembelajaran dilaksanakan dari rumah masingmasing. Sejak adanya edaran pemerintah untuk belajar dari rumah, SD STKIP Muhammadiyah Bangka Belitung telah melaksanakan BdR selama 3 bulan hingga September 2020. Tanggapan orang tua siswa terhadap kebijakan yang dikeluarkan oleh pihak sekolah beraneka ragam. Hasil pertemuan pihak sekolah bersama orang tua siswa saat menyampaikan kebijakan ini 38\% menyatakan setuju

${ }^{12}$ Maulina Hendrik and Roslinah Roslinah, "Kemampuan Memahami Bacaan Melalui Teknik Skimming dengan Taktik Menggarisbawahi Ide-Ide Kunci pada dan $62 \%$ menyatakan tidak setuju. Orang tua yang menyatakan tidak setuju pada dasarnya adalah para orang tua yang kesehariannya bekerja di luar rumah sehingga saat mengetahui kebijakan ini harus memikirkan kebutuhan anaknya selama di rumah saat orang tua bekerja.

Teknis pembelajaran yang dilakukan yaitu guru dan siswa belajar jarak jauh dengan memanfaatkan whatsapp. Kepala sekolah mengakui bahwa saat itu kami belum ada persiapan untuk melaksanakan pembelajaran dari rumah secara daring. "Jangankan kami, sekolah senior saja masih mencari solusi pertama menanggapi kebijakan pemerintah saat ini. Tetapi kami tidak pantang menyerah, Saya yakin guru-guru mampu mengatasi permasalahan ini." Seperti yang diungkapkan Hendrik ${ }^{12}$ "Peran seorang guru dalam menghasilkan perubahan perilaku sangat besar, akan menjadi cambuk bagi seorang guru dalam memberikan pengajaran untuk lebih ekstra dalam proses pembelajaran agar siswa dapat memperoleh pemahaman yang menghasilkan prestasi gemilang."

Minggu pertama hingga ketiga yang dilakukan guru bersama siswa adalah belajar melalui aplikasi whatsapp dan youtube. Masing-masing guru kelas memanfaatkan grup wa orang tua yang selama ini dimanfaatkan untuk menyampaikan hasil belajar siswa maupun berdiskusi. Selain whatsapp, guru mulai percaya diri untuk menggunakan aplikasi lainnya seperti zoom dan google meet.

Siswa Kelas IV SD Negeri 11 Pangkalpinang," JINoP (Jurnal Inovasi Pembelajaran), 2019, https://doi.org/10.22219/jinop.v5i1.7190. 


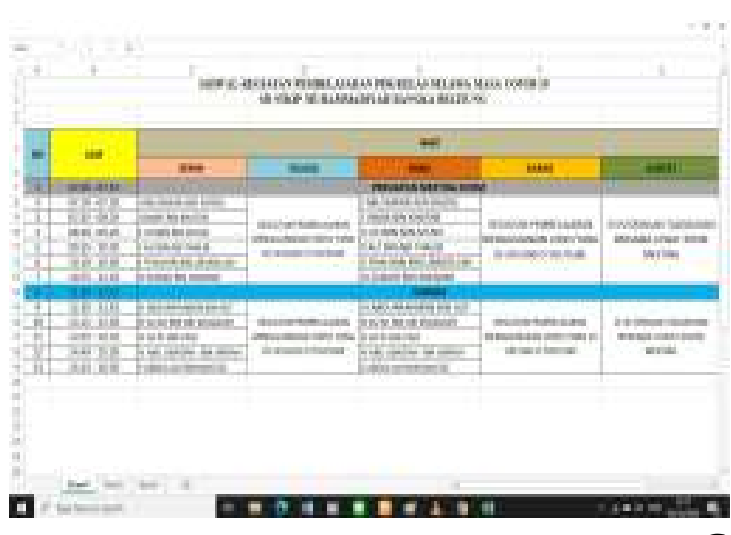

Gambar 2.

Jadwal Pembelajaran Selama Masa Covid-19

Setelah guru bersama kepala

Berdasarkan gambar 2 tersebut, pembelajaran di SD STKIP Muhammadiyah Bangka Belitung dilakukan dengan cara sinkron dan asinkron, yaitu memanfaatkan media youtube dan zoom.

Orang tua sebagai penghubung antara guru dan siswa ikut proaktif saat siswa belajar. Kerja sama antara guru dengan siswa juga dipengaruhi oleh keterlibatan orang tua. Tidak hanya guru, orang tua juga sebagai fasilitator, bertugas mengamati dan mendampingi anaknya selama belajar dari rumah.
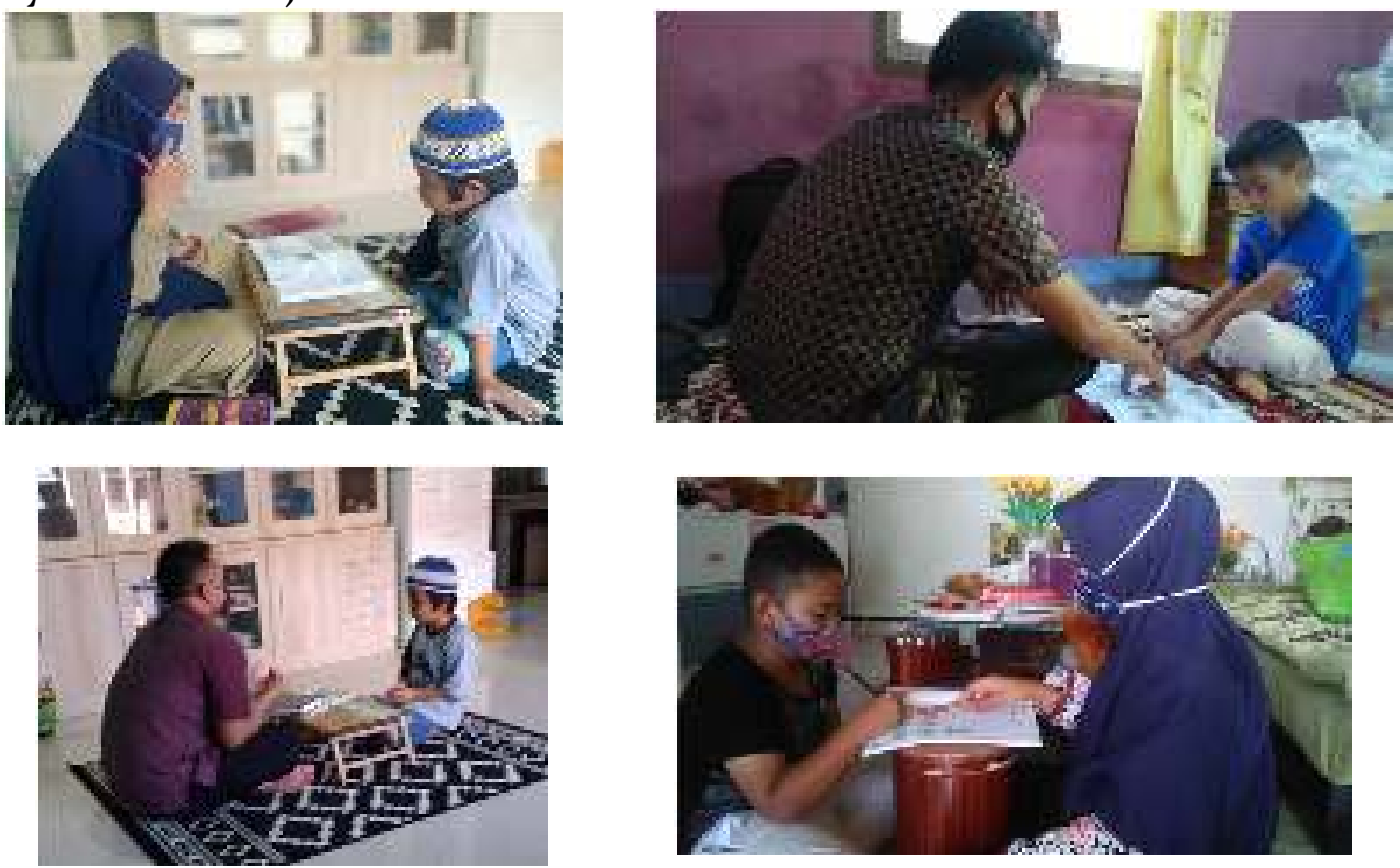

Gambar 2.

Aktivitas pembelajaran di rumah siswa 
2. Wujud kerja sama antara guru dengan siswa selama BdR di SD STKIP Muhammadiyah Bangka Belitung

Pelaksanaan pembelajaran secara daring penuh dilakukan selama 3 minggu pertama saat kebijakan BdR diterapkan. Selain itu, pembelajaran berlangsung dengan metode blended learning, yaitu melalui zoom/ google meet dan tatap muka di rumah siswa. Kerja sama antara guru dengan siswa yang terjadi saat pembelajaran berlangsung:

a. Kerja sama sebagai fasilitator (antara guru dengan orang tua)

Kerja sama ini merupakan dasar sebuah aktivitas pembelajaran dikatakan berhasil. Fasilitator yang dimaksudkan adalah orang tua memfasilitasi anaknya agar dapat berkomunikasi dengan guru baik secara daring (zoom) maupun tatap muka di rumah. Hal ini dilakukan karena siswa tidak mampu secara penuh menggunakan perangkat pembelajaran digital seperti penggunaan laptop, zoom, dan sebagainya. Selain itu juga, kerja sama yang terjadi orang tua membantu menyampaikan pesan guru kepada anaknya. Guru menyampaikan tugas atau materi melalui pesan whatsapp kepada siswa melalui orang tua. Kondisi ini diharuskan karena anakanak tidak dapat belajar secara mandiri. Keterlibatan orangtua dalam mengajar relevan dengan penelitian yang pernah dilakukan oleh Junianto D dan Wagiran dalam Miftakhi dan Hendrik ${ }^{13}$, bahwa keterlibatan orangtua dalam pendidikan anak berpengaruh terhadap motivasi berprestasi.

Orang tua siswa SD STKIP Muhammadiyah Bangka Belitung sebanyak $88 \%$ berperan sebagai fasilitator selama pembelajaran daring. Sebanyak $12 \%$ orang tua siswa ikut berperan tetapi tidak secara langsung yaitu meminta pengasuh atau orang lain untuk mendampingi anaknya belajar khususnya melalui zoom. Hal tersebut dikarenakan orang tua yang aktif bekerja sejak pagi hingga sore hari. Contoh kerja sama orang tua dan guru saat belajar menggunakan whatsapp.
13 Diah Rina Miftakhi and Maulina Hendrik, "Implementasi Program Gerakan Orangtua Mengajar Untuk Meningkatkan Motivasi Belajar Siswa," Jurnal Psikologi
Pendidikan Dan Konseling: Jurnal Kajian Psikologi Pendidikan Dan Bimbingan Konseling, 2018 https://doi.org/10.26858/jpkk.v4i2.7150. 


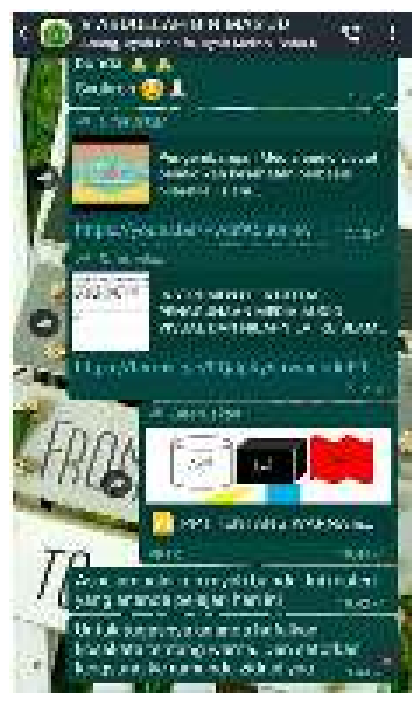

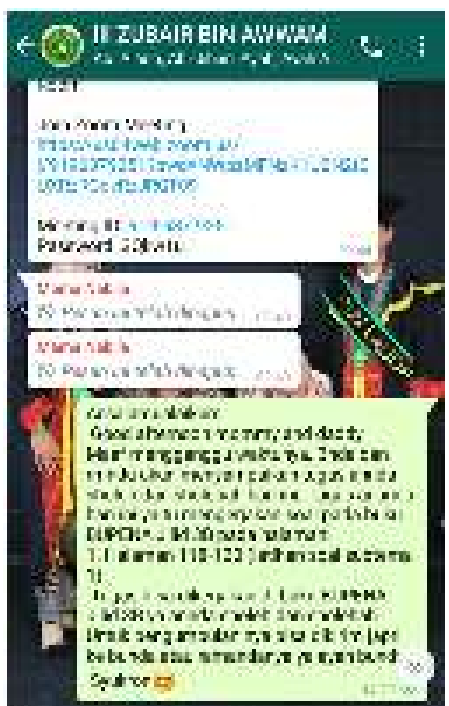

Gambar 3.

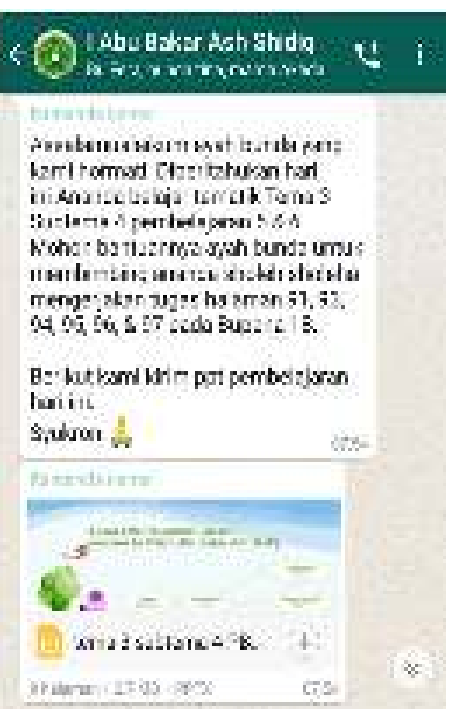

manzistos ars

Kerja sama orang tua bersama guru melalui whatsapp
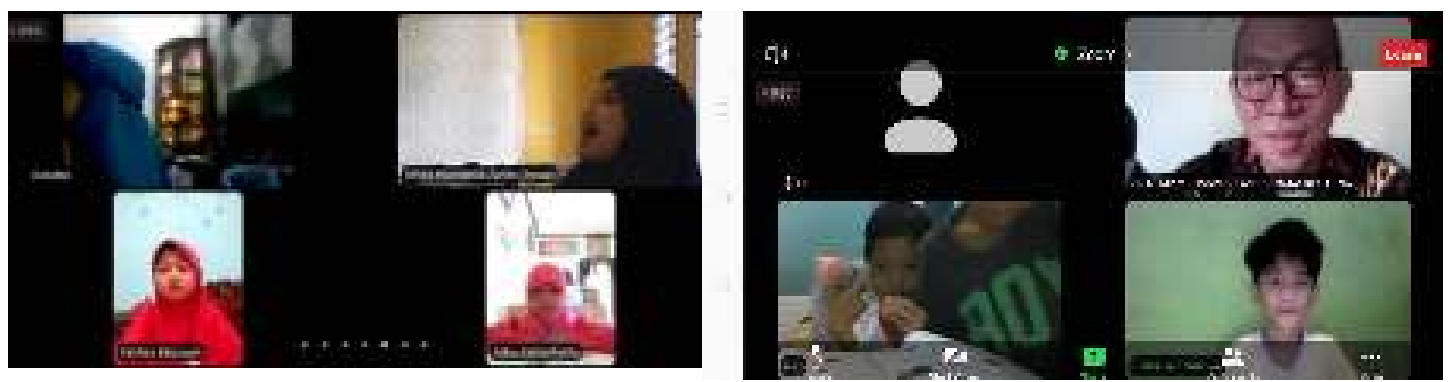

Gambar 4.

Aktivitas pembelajaran SD STKIP Muhammadiyah Bangka Belitung melalui zoom

b. Kerja sama antarsiswa dan antara siswa dengan guru

Selama proses pembelajaran melalui zoom, peneliti berperan sebagai observer langsung dengan cara sembunyi di balik layar zoom (hide video non participant). Selama pembelajaran, kerja sama yang terjadi baik antarsiswa maupun antara guru dengan siswa berdasarkan 3 indikator:

1) hadir tepat waktu,

2) menghargai pendapat guru dan teman sebaya, dan

3) menyelesaikan tugas tepat waktu.
Berdasarkan laporan presensi siswa selama pembelajaran rata-rata kehadiran siswa yang tepat waktu sebesar 55\%. Artinya, sebanyak 22 siswa rata-rata jumlah siswa per kelas, yang hadir tepat waktu selama pembelajaran sebanyak 12 orang siswa baik di kelas I, 3, dan 5. Ketidakhadiran siswa tepat waktu disebabkan motivasi siswa untuk belajar secara daring masih kurang. Siswa beranggapan belajar tidak secara langsung di kelas bukanlah sekolah. Selain itu, sebab tidak tepat waktu hadir di ruang zoom, banyak yang terkendala oleh sinyal. Guru selalu memulai pelajaran tepat waktu yaitu pukul 7.10, 11.0o, dan pukul 16.30 WIB. Sebelum 
memulai, guru selalu menyisihkan waktu 10 menit untuk mempersiapkan ruang zoom dan menunggu siswa hadir layaknya pembelajaran tatap muka di kelas. Guru harus mampu mengelola kelas sebelum pembelajaran di mulai.

Selain kerja sama dalam hal hadir tepat waktu, kerja sama antarsiswa diukur dari cara siswa menghargai pendapat guru dan teman sebayanya. Menghargai pendapat orang lain merupakan pengamalan sila ke-4 "Kerakyatan yang dipimpin oleh hikmat kebijaksanaan dalam permusyawaratan/ perwakilan.” Artinya yang dikedepankan prinsip bermusyawarah untuk mufakat. Begitu pula implementasi kerja sama dalam pembelajaran, guru menghargai pendapat atau jawaban siswa, siswa menghargai pendapat teman sebayanya, dan juga siswa menerima pendapat guru. Selama pengamatan berlangsung, siswa yang benar-benar mendengar pendapat teman sebaya dan guru sebanyak $79 \%$ yang berarti siswa tersebut menyimak hal-hal yang didiskusikan, menyimak rekanrekannya menjawab pertanyaan guru. Sedangkan $11 \%$ rata-rata siswa yang menjadi subjek penelitian mengakui tidak dapat mendengar dengan jelas sebab sinyal yang tidak stabil sehingga terlihat seperti mengacuhkan teman maupun gurunya sedang berbicara. Tampak saat pembelajaran berlangsung, siswa asyik dengan kegiatannya sendiri, membaca buku padahal sedang berdiskusi, dan sebagainya. Hal tersebut dibuktikan dari percakapan guru dengan siswanya:

"Ashari...apakah paham yang disampaikan athifa?"

"ari tidak dengar jelas bu, putus-putus."
Kerja sama yang ketiga adalah menyelesaikan tugas tepat waktu. Selama pembelajaran dari rumah tentunya pembelajaran tidak terlepas dari tugas karena pertemuan tatap muka langsung yang membatasi. Siswa yang selalu menyerahkan tugas tepat waktu kepada guru sebanyak $48 \%$ atau ratarata setiap kelas 11 orang. Tugas yang diserahkan kepada guru bentuknya bervariasi baik melalui rekaman video, tugas tertulis, maupun rekaman suara. Tugas yang diberikan kepada siswa untuk menjamin bahwa siswa memahami transfer materi oleh guru baik melalui whatsapp maupun zoom.

3. Faktor-faktor yang menghambat terjalinnya kerja sama antara guru dengan siswa selama pembelajaran daring di SD STKIP Muhammadiyah Bangka Belitung

Sebaik apapun metode atau cara yang digunakan guru selama pembelajaran daring tentunya memiliki kekurangan. Kekurangan tersebut menjadi faktor-faktor yang menghambat jalannya pembelajaran. Belajar dari rumah memang terlihat lebih mudah, tetapi dalam penerapannya justru banyak kendala. Secara teoritis, kendala tersebut dapat berasal dari guru maupun orang tua dan siswa. Faktor-faktor yang menghambat terjalinnya kerja sama antara guru dengan siswa selama pembelajaran daring antara lain

a. Antusias siswa

Antusias siswa belajar secara daring sangat kurang. Penyebabnya adalah: tidak dapat bertemu teman dan bermain bersama, sulit memahami pelajaran, tidak fokus karena lingkungan sekitarnya kurang kondusif.

b. Sarana dan Prasarana pembelajaran 
Sarana dan prasarana pembelajaran menjadi faktor yang mempengaruhi jalannya aktivitas pembelajaran. Kelemahan pihak guru SD STKIP Muhammadiyah Bangka Belitung dalam menyediakan sarana pembelajaran adalah ruang pertemuan secara daring yang sangat minim dari segi waktu. Penggunaan zoom hanya 1 jam 1 kelas per pertemuan membuat pertemuan tergesa-gesa meskipun 1 pertemuan tidak harus dihabiskan secara daring melalui zoom. Selain itu, guru tidak dapat secara penuh berkomunikasi dengan siswa secara bergantian karena penyediaan waktu yang terbatas.

c. Peranan dan kompetensi orang tua

Peranan orang tua merupakan faktor utama. Orang tua yang selalu beraktivitas secara daring tidak semuanya antusias secara aktif mendampingi anak-anaknya. Gangguan sinyal merupakan penyebab antusiasme para orang tua menurun. Selain itu, mayoritas orang tua siswa adalah pekerja sehingga peranan mendampingi anaknya belajar penuh waktu secara daring sangat kurang. Kompetensi orang tua tanggap teknologi juga berpengaruh terhadap kerja sama pembelajaran secara daring. Orang tua yang tidak memiliki fasilitas belajar daring akan kesulitan menyiapkan anaknya belajar daring.

d. Mata pelajaran berbasis praktikum

Faktor lainnya yang menghambat kerja sama dalam pembelajaran adalah pada mata pelajaran praktik, seperti olahraga, seni budaya, dan beberapa muatan pelajaran semi praktik. Saat pembelajaran siswa sangat antusias namun guru tidak dapat mengontrol satu per satu siswa dikarenakan di ruang zoom tidak dapat menangkap semua siswa dalam 1 layar penuh sehingga siswa yang berada di ruang lain tidak bisa diperhatikan secara intens.

\section{SIMPULAN}

Penelitian ini bertujuan untuk mendeskripsikan: 1) pelaksanaan pembelajaran selama belajar dari rumah di masa pendemi Covid-19; 2) wujud kerja sama antara siswa dengan guru selama pembelajaran daring pada masa pandemi Covid-19 di SD STKIP Muhammadiyah Bangka Belitung; dan 3) faktor-faktor yang menghambat terjalinnya kerja sama antara guru dengan siswa selama pembelajaran daring. Hasil analisis data menunjukkan: 1) Pola pelaksanaan pembelajaran di SD STKIP Muhammadiyah Bangka Belitung selama belajar dari rumah di masa Covid-19 adalah secara virtual dan tatap muka door to door. 2) Kerja sama antara guru dan siswa cukup baik selama pembelajaran daring berdasarkan 3 indikator: hadir tepat waktu, menghargai pendapat guru dan teman sebaya, dan menyelesaikan tugas tepat waktu. Siswa yang hadir tepat waktu selama pembelajaran daring sebanyak $55 \%$. Siswa yang menghargai/menyimak pendapat temannya saat belajar menggunakan zoom sebanyak 79\%, dan siswa yang selalu menyerahkan tugas kepada guru tepat waktu sebanyak $48 \%$. 3) faktor-faktor yang menghambat terjalinnya kerja sama antara guru dengan siswa selama pembelajaran daring yaitu: antusias siswa, sarana dan prasarana pembelajaran, peranan dan kompetensi orang tua, serta mata pelajaran berbasis praktikum. 
DAFTAR PUSTAKA

Asmuni. "Problematika Pembelajaran Daring Di Masa Pandemi Covid19 Dan Solusi Pemecahannya" 7, no. 4 (2020): $281-88$.

Creswell, J.W., and J. David Creswell. Research and Design Qualitative, Quantitative and Mixed Methods Approaches. Thousand Oaks California, 2018.

Dewi, Noviana, and Stefanus Khrismasagung Trikusumaadi. "Bahaya Kecanduan Internet Dan Kecemasan Komunikasi Terhadap Karakter Kerja Sama Pada Mahasiswa." Jurnal Psikologi, 2017. https://doi.org/10.22146/jpsi.1682 9.

Greenstein, Laura. "Assessing 21st Century Skills: A Guide to Evaluating Mastery and Authentic Learning." Assessing 21st Century Skills: A Guide to Evaluating Mastery and Authentic Learning, 2012.

Hendrik, Maulina, and Roslinah Roslinah. "KEMAMPUAN MEMAHAMI BACAAN MELALUI TEKNIK SKIMMING DENGAN

TAKTIK

MENGGARISBAWAHI IDE-IDE KUNCI PADA SISWA KELAS IV SD NEGERI 11 PANGKALPINANG.” JINoP (Jurnal Inovasi Pembelajaran), 2019.

https://doi.org/10.22219/jinop.v5i 1.7190.

Miftakhi, Diah Rina, and Maulina Hendrik. "Implementasi Program Gerakan Orangtua Mengajar Untuk Meningkatkan Motivasi Belajar Siswa." Jurnal Psikologi Pendidikan Dan Konseling: Jurnal Kajian Psikologi Pendidikan Dan
Bimbingan Konseling, 2018. https://doi.org/10.26858/jpkk.v4i 2.7150.

Pramesti, Diana, and Adevia Indah Kusuma. "Implementasi Nilai Kewirausahaan Jenjang Sekolah Dasar Pada Sekolah Mitra Stkip Muhammadiyah Bangka Belitung Di Kecamatan Gabek Kota Pangkalpinang." Jurnal Ekonomi Dan Pendidikan 17, no. 1 (2020): 16.

https://doi.org/10.21831/jep.v17i1. 29256.

Purwanto, Agus, Rudy Pramono, Masduki Asbari, Priyono Budi Santoso, Laksmi Mayesti Wijayanti, Chi Hyun Choi, and Ratna Setyowati Putri. "Studi Eksploratif Dampak Pandemi COVID-19 Terhadap Proses Pembelajaran Online Di Sekolah Dasar." EduPsyCouns: Journal of Education, Psychology and Counseling, 2020.

Rahardjo, Mudjia. "STUDI KASUS

DALAM PENELITIAN KUALITATIF: KONSEP DAN PROSEDURNYA." Repository UIN MALANG, 2017.

Syah, Rizqon H. "Dampak Covid-19 Pada Pendidikan Di Indonesia: Sekolah, Keterampilan, Dan Proses Pembelajaran." SALAM: Jurnal Sosial Dan Budaya Syar-I, 2020.

https://doi.org/10.15408/sjsbs.v7i 5.15314.

Wiedarti, Pangesti, and Kisyani Laksono. Panduan Gerakan Literasi Sekolah Di Sekolah Dasar. Direktorat Pembinaan Sekolah Dasar Direktorat Jenderal Pendidikan Dasar Dan Menengah Kementerian Pendidikan Dan Kebudayaan, 
2016.

https://doi.org/10.1007/s10029-

017-1595-X.

Yulianti, Silvi Dwi, Eri Tri Djatmika, and Anang Susanto. "Pendidikan Karakter Kerja Sama Dalam
Pembelajaran Siswa Sekolah Dasar Pada Kurikulum 2013.” Jurnal Teori Dan Praksis Pembelajaran IPS, 2016. https://doi.org/10.17977/umo22v1 i12016po33. 